\title{
FROM PRIVATE COLLECTIONS TO ARCHIVES: HOW CHRISTIANS KEPT ARABIC LEGAL DOCUMENTS IN GRANADA $^{1}$
}

\author{
DE COLECCIONES PRIVADAS A ARCHIVOS: SOBRE CÓMO \\ LOS CRISTIANOS GUARDARON DOCUMENTOS ÁRABES \\ LEGALES EN GRANADA
}

\author{
Amalia Zomeño \\ CCHS - CSIC
}

This paper studies several collections of Arabic legal documents preserved in Granada from the perspective of the "archival mind". It focuses on how and why these documents survived, but also on who thought they were worth archiving. This study contributes to an understanding of how individuals who lived in the Mudejar and Morisco periods reacted towards their documents.

Key words: Islamic Law; Notaries; Arabic documents; Archives.

\begin{abstract}
Este trabajo estudia algunas colecciones de documentos notariales árabes que se han conservado en Granada, desde el punto de vista de la mentalidad de archivo. Está especialmente enfocado al análisis de cómo y por qué sobrevivieron estos documentos y quién pudo pensar que se trataba de un material que merecía ser preservado. Este estudio contribuye a conocer mejor el comportamiento de los habitantes de Granada hacia los documentos árabes.
\end{abstract}

Palabras clave: Derecho islámico; notariado; documentos árabes; archivos.

\section{Introduction}

The jurists of al-Andalus produced several manuals for notaries (muwaththiqūn). ${ }^{2}$ These manuals provided models for all kinds of

1 The research for this paper was conducted within the research group "Teoría y práctica notariales en la Granada nazarí y mudejar a través de los documentos arábigogranadinos" funded by MICINN (FFI2009-09897). It is also the product of my participation in the ERC group "Islamic Law Materialized" directed by Christian Müller (IRHT).

2 The edited texts are: Ibn al-'Atțār, Formulario notarial hispano-árabe por el alfaquí y notario cordobés Ibn al-'Atțär (s. X), ed. P. Chalmeta and F. Corriente, Madrid, 1983; Ibn al-'Ațāar, Formulario notarial y judicial andalusí del alfaquí y notario cor- 
legal transactions, explaining their use and adding the jurisprudence on the issues concerned. ${ }^{3}$ However, only a limited number of these documents has survived until today. In this paper, instead of wondering why so many Andalusi legal documents have perished, I propose to study those which still exist.

I will study the main collections of Arabic legal documents safeguarded in Granada from the perspective of archival mentalities or the "archival mind". I will focus on how and why these documents survived, but also on who thought they were worth preserving from degradation. It will also be necessary to know something about the criteria for their preservation: why did these and not others survive?

The answer is only partially known, because the Arabic legal documents are now held in what used to be, and sometimes still are, "Christian archives". ${ }^{4}$ The conquerors of Granada in 1492, their new owners, preserved these Arabic documents even if, as Eduardo Manzano pointed out, "they referred to a past that was increasingly alien to them". ${ }^{5}$

But it is also clear that they would only have preserved what they selected among what they actually found, and this is certainly not well known. From the study of the existing documents, it seems clear, as I will try to show in this paper, that the conquerors did not find archives systematically kept by Muslim institutions. What we do

dobés m. 399/1009 Ibn al- 'Attēarr, transl. and notes P. Chalmeta and M. Marugán, Madrid, 2000; Ibn Mughīth al-Ṭulayțulī, Aḥmad, al-Mughnī fì 'ilm al-shurūt, ed. and introd. by F.J. Aguirre Sádaba, Madrid, 1994; al-Jazīin̄, 'Alī b. Yahyà, al-Maqșad al-mahmūd fì talkhīs al-'uqūd. Proyecto plausible de compendio de fórmulas notariales, ed. and study by A. Ferreras, Madrid, 1998; Ibn Salmūn al-Kinānī, Kitāb al- 'iqd al-munazzam li-l-hukkām fì-mā yajrì bayna aydì-him min al-'uqūd wa-l-ahkām, ed. in the margins of Tabșirat al-hukkām by Ibn Farḥūn, Cairo, 1885; al-Gharnāțī, Abū Isḥāq, al-Wathā'iq al-mukhtașara, ed. Mușțafà Nājīi, Rabat, 1988.

${ }^{3}$ Hallaq, W.B., "Model Shurūt Works and the Dialectic of Theory and Practice", Islamic Law and Society, 2 (1995), 109-134; López Ortiz, J., "Formularios notariales de la España musulmana", La ciudad de Dios, 145 (1926), 260-272.

${ }^{4}$ For a general and updated overview of the Granadan collections, see Barceló, C. and Labarta, A., "Los documentos árabes del Reino de Granada. Bibliografía y perspectivas", Cuadernos de la Alhambra, 26 (1990), 113-9 and Álvarez de Morales, C., "La geografía documental arábigogranadina", in Martínez de Castilla, N. (ed.), Documentos y manuscritos árabes del Occidente musulmán medieval, Madrid, 2010, 205-223.

${ }^{5}$ Manzano Moreno, E., "Introduction", in P.M. Sijpesteijn, L. Sundelin, S. Torallas and A. Zomeño (eds.), From al-Andalus to Khurasan. Documents from the Medieval Islamic World, Leiden, 2007, xvii-xxviii, xxvii.

Al-Qantara XXXII 2, julio-diciembre 2011, pp. 461-479 ISSN 0211-3589 
know is that the documents were given to Christian institutions in many different circumstances that should be studied.

For this transfer of documentary material, the Mudejar period (1492-1500) is crucial. Thanks to the Capitulaciones (agreements) between the emir Abū 'Abd Allāh and the Catholic Monarchs, the Muslim population of Granada was allowed to remain in the city and maintain its religion, its properties and the validity of its documents. ${ }^{6}$ This allowed the transmission of both properties and documentary material from Muslim to Christian hands to happen only gradually. ${ }^{7}$

This study focuses on individuals who lived during this unstable period, and on how they reacted towards their documents. Perhaps the most illustrative example is that of Muhammad al-Qirbilyānī, whose name came to light in the 1950s when the owner of a house in Baza decided to refurbish his home and removed a wall from it. Inside the wall, he found some Arabic documents, wrapped in a green cloth. These documents were handed over to Luis Seco de Lucena, who edited most of them. ${ }^{8}$ Since many of the documents mentioned Muhammad al-Qirbilyān̄, Seco de Lucena correctly deduced that the bundle was that man's family archive, i.e. the collection of documents that al-Qirbilyānī might have kept at home. It contains some legal documents, dated between 859/1455 and 889/1485, but also letters and various notes. In Seco de Lucena's view, al-Qirbilyānī probably cared so much about them that, when the Christians conquered the city of Baza on the 10 Muharram 895 / 4 December 1489 after a siege which lasted five months, ${ }^{9}$ he built a wall and hid the documents inside, then left the city in the hope of coming back at a later date to find them safely preserved. However, we cannot in fact be certain

${ }^{6}$ On these agreements, see Garrido Atienza, M., Las capitulaciones para la entrega de Granada, Granada, 1992 and López de Coca Castañer, J.E., "Las capitulaciones y la Granada mudéjar", in Ladero Quesada, M.A. (ed.), La incorporación de Granada a la Corona de Castilla, Granada, 1993, 263-305.

${ }^{7}$ Molina López, E. and Jiménez Mata, M.C., "From Muslim to Christian Hands: The Documents from the Municipal Archive of Granada", in Sijpesteijn, Sundelin, Torallas and Zomeño (eds.), From al-Andalus to Khurasan, 23-38.

${ }^{8}$ On this collection, see Seco de Lucena, L., "Un nuevo texto en árabe dialectal granadino", Al-Andalus, 20 (1955), 153-65 and Seco de Lucena, L., "Actas notariales arábigo-granadinas", MEAH, 2 (1953), 99-107, 105.

9 Vidal Castro, F., "Historia política", en M.J. Viguera Molins (coord.), El Reino Nazari de Granada. Política. Instituciones. Espacio y economía. VIII. III, Madrid, 2000, 47-248, 204-5.

Al-Qanțara XXXII 2, julio-diciembre 2011, pp. 461-479 ISSN 0211-3589 
when the collection was hidden: it may have occurred during the siege of Baza, or even after the entry of the Christians. Alternatively, al-Qirbilyānī may have decided to stay in Baza and only hid the documents much later, when Arabic writings were forbidden, for fear that they would be destroyed by Spaniards or by the Inquisition well into the 16th century.

This collection is therefore an excellent example of what a Muslim might have considered worth keeping in his house and deemed necessary to preserve. The fact that the papers were hidden means that al-Qirbilyānī did not give them to anyone, so they did not undergo the same process as the other documents held in the archives of the conquerors. On the other hand, if the documents remained hidden, then it seems clear that al-Qirbilyānī never came back for them.

Finally, I propose to incorporate the study of these Granadan collections into the general discussion on the scarcity of legal documents for the whole Medieval period in Islamic societies and, indirectly, on the lack of an "archival mind" which such a scarcity is said to reveal. ${ }^{10}$

Authors have proposed a number of reasons for this paucity of documentary sources, and they can be summarized under four headings: 1) degradation of dereliction in times of political instability, 2) the nature of Islamic law, which does not encourage archival behavior, 3) the fact that social groups and elites did not rely on legal documents for their survival and 4) the fact that the Christians destroyed the written materials of the Arabic Muslim past. Let us examine each of these four reasons through the analysis of the Arabic legal documents preserved in Granada.

${ }^{10}$ Manzano Moreno, "Introduction"; Sijpesteijn, P.M., "The Archival Mind in Early Islamic Egypt: Two Arabic Papyri”, in Sijpesteijn, Sundelin, Torallas and Zomeño (eds.), From al-Andalus to Khurasan, 163-86; Manzano Moreno, E., Conquistadores, emires y califas. Los Omeyas y la formación de al-Andalus, Barcelona, 2006, 392-415; Hallaq, "Model Shurūt Works"; Fierro, M., "Documentos legales en fuentes andalusíes", Al-Qantara, 22 (2001), 205-209; Chamberlain, M., Knowledge and Social Practice in Medieval Damascus, 1190-1350, Cambridge, 1992, 2-18; Humphreys, R.S., Islamic History: A Framework for Inquiry, London, 1991, 40-49; Chalmeta, P., "De historia hispano-musulmana: reflexiones y perspectivas", Revista de la Universidad de Madrid, 20 (1972), 129-60.

Al-Qanțara XXXII 2, julio-diciembre 2011, pp. 461-479 ISSN 0211-3589 


\section{Degradation and loss over time}

The first reason given by scholars for the scarcity of Arabic documents is accidental loss. Unfavorable climate conditions in certain areas together with the bad quality of writing materials may have resulted in a fatal degradation of the documents. As an explanation for the scarcity of old written materials, this factor cannot be denied, but it does not help in understanding how other documents did survive, such as many other older texts which were not Arabic legal documents. Political instability, wars, and the lack of a continued existence of institutions and dynasties provide other reasons of considerable importance, especially in al-Andalus. ${ }^{11}$

This is, without doubt, one of the reasons for the loss of large numbers of documents and also explains the inadequate conditions in which many documents, manuscripts and other perishable objects did endure. However, this factor should not be used to promote the idea that the Arabic legal documents that actually survived did so because of "accidental keeping", hazardous circumstances or chance. My main point is that the existing collections survived because they were intentionally protected from the degradation of time and politics, as in the case of Muḥammad al-Qirbilyānī's papers. ${ }^{12}$

\section{Islamic Law and Documents}

The second reason given for the scarcity of Arabic legal documents from the Medieval period is the nature of Islamic law, which has been said not to encourage archival behavior from the judiciary or subsequently, subjects of the law. It is argued that this happens for several reasons:

\section{The production of documents}

The rules and norms of Islamic law, even procedural laws, were very well known as a result of the close and advice-giving relation-

11 Manzano Moreno, Conquistadores, emires y califas, 393.

12 Such was also the case in the Latin West, as is pointed out by Manzano Moreno, "Introduction", xix, xxvii; see also Chamberlain, Knowledge and Social Practice, 3, 13. 
ship between jurists and subjects of the law. Since both sides knew that these well-known norms would be systematically applied, it has been argued that the parties did not necessarily need to write down legal contracts and their details. ${ }^{13}$

However, this is no longer an acceptable explanation because our knowledge of the fatwa -giving process shows that they were precisely the muftis and other jurists who advised Muslims to write down their legal agreements. This is borne out by other legal sources.

In fact, such documents were produced in massive quantities. The documents were issued by a well defined group of professionals, the notaries (muwaththiqūn), ${ }^{14}$ who worked in Granada and followed common criteria and conventions for their standardized narration of legal matters. If we take into account the material format of these texts, it can be seen that all the documents from the various different collections are remarkably similar: most notaries used the same kind of paper, reserving parchment for special occasions, and the documents are all of a very similar size, with black ink and the same conventions for the correction of mistakes, the placement of signatures, validations, spaces for amendments and clear margins on the right.

The documents also share the same formula for each transaction following the same manual, although introducing some changes in relation with the manuals. ${ }^{15}$ Of the wide variety of legal matters standardized in the manuals for notaries, the ones that survived in written form mostly relate to the transfer of immovable properties (especially and mostly sale contracts, but also donations, exchanges, legacies, and divisions of inheritances). Another group of documents relates to commitments made by individuals, such as mandates and other obligations.

${ }^{13}$ Guichard, P., Al-Andalus frente a la conquista cristiana. Los musulmanes de Valencia (siglos XI-XIII), Valencia-Madrid, 2001, 28-9. For a discussion of this, see Manzano Moreno, Conquistadores, emires y califas, 392.

${ }^{14}$ On notaries in al-Andalus, see Cano Ávila, P., "El notario musulmán andalusí", in Actas del II Coloquio Hispano-Marroqui de Ciencias Históricas "Historia, Ciencia y Sociedad", Madrid, 1992, 89-106; Tyan, E., Le notariat et le régime de la prueve par écrit dans la pratique du droit musulman, Beirut, 1959; Zomeño, A., "Notaries and Their Formulas: The Legacies from the University Library of Granada" in Sijpesteijn, Sundelin, Torallas and Zomeño (eds.), From al-Andalus to Khurasan, 59-77.

${ }^{15}$ On this, see my "Notaries and their formulas". See also the introduction by Seco de Lucena, L. in his Documentos arábigo-granadinos, Madrid, 1961.

Al-Qantara XXXII 2, julio-diciembre 2011, pp. 461-479 ISSN 0211-3589 
The documents recording transfers of real estate typically include a detailed description of the object being sold, i.e. land, plot or house. The additional value of these documents, apart from being a proof of who owned the property, was that they were indisputably useful for knowing the limits and extension of such properties. The incentive for keeping them was therefore huge, as we will see later. The function of notaries was thus not only technical, as writers of documents, but specifically related to their status as experts in Islamic law and legal procedures, since the documents were produced with the aim of being effective in court.

\section{The use of legal documents}

The second reason for the scarcity of legal documents related to Islamic law has to do with the general consideration of oral testimony over written evidence, and therefore the limited value of documents in court and in a litigation process, since they only constituted an indication (dalīl) and not full legal evidence (bayyina). ${ }^{16}$

This means that if a Muslim in Granada was challenged on the use of a piece of land that he considered to be his property, he had to go to court with his sale contract and show it to the judge. However, the judge himself would only accept the facts narrated in this contract if the professional witnesses, who wrote the deed, confirmed in his presence that the signatures in the document were theirs. All the extant documents issued in Granada are validated by the signatures of two professional witnesses, but do not bear any trace of their presence at court. Therefore, these documents seem never to have been used at court, although they would have been folly effective if a case had made this necessary. Nevertheless, whether they were valid or not, these documents were certainly preserved, at least for some time.

Only a limited number of documents in the surviving collections bear traces of judicial activity in their texts. In fact, once the document was corroborated in court, the judge, or his kâtib, wrote the

${ }^{16}$ Guichard, Al-Andalus frente a la conquista, 28 and 30. On this subject according to Islamic law, see Schacht, J., An Introduction to Islamic Law, Oxford, 1964, 82, 84; Tyan, Le notariat, 6; Müller, C., "Écrire pour établir la preuve orale en Islam. La pratique d'un tribunal à Jérusalem au XIVe siècle", in A. Saito and Y. Nakamura (dirs.), Les outils de la pensée. Étude historique et comparative des "textes", Paris, 2010, 63-97. 
word "enough" (iktafā) at the end of the text. ${ }^{17}$ Thubita or thubita $b i-w a \overline{a j i b i-h i}$ is another formula which, in my opinion, had the same function as a judicial validation of the document. ${ }^{18} \mathrm{Ibn}$ 'Āsim explains that $i k t a f \bar{a}$ means that the witnesses corroborated their testimony in front of the $q \bar{a} d \bar{l}$, who was, therefore, satisfied. ${ }^{19}$

This was the preferred formula for validating a legally standardized written narration of certain facts, typically an appraisal by experts (ahl al-bașr wa-l-ma 'rifa) ${ }^{20}$ but it is also seen in documents relating to testimony concerning the ownership of immovable properties $(h i y \bar{a} z a)$ or in a death certificate for a man who had died on a battlefield. ${ }^{21}$ These statements were not always made by professional witnesses and therefore their 'adāla or honorability was not asserted by the judge, meaning that their testimony had to be confirmed at court.

Returning to the question of the survival of Arabic legal documents and its dependence on their value as legal evidence, the Granadan deeds permit us to conclude that what made the Muslims keep their documents was not the fact that they were validated, but rather the fact that the notaries had issued documents potentially capable of ensuring their owners' rights in future lawsuits.

${ }_{17}$ Seco de Lucena, Documentos arábigo-granadinos, no. 26.

18 See Seco de Lucena, Documentos arábigo-granadinos, no. 7; Seco de Lucena, L., "Escrituras árabes de la Universidad de Granada", Al-Andalus, 35 (1970), 315-53, nos. 19, 51. See also iktafā bi-l-wäjib in Seco de Lucena, Documentos arábigo-granadinos, no. 14 .

19 See Ibn 'Āssim, La Tohfat d'Ebn Acem: Traité de droit musulman, ed. and transl. by O. Houdas and F. Martel, Algiers, 1882, verse 87, p. 41. See also notes 48 and 49 on the commentaries there. Other documents include a parallel formula, a lama bithubüti-hi or a 'lama bi-iktifá'i-hi, and as Ibn 'Āṣim again points out, it is clearly stated that the $q \bar{a} d \bar{\imath}$ informs about his validation of the document. However, the more exact meaning is that the document could be sent to another $q \bar{a} d \bar{l}$, who through this formula knew the validations of the procedure carried out by his colleague, and this formed the khitab or seal of the judge. M. b. A. Miyyāra al-Fāsī, Sharh Tuḩat al-ḥukkām, El Cairo, 1315/1898, 46-8. See Seco de Lucena, Documentos arábigo-granadinos, nos. 15, 16, 19, 20, 33 and 56 and also Seco de Lucena, "Escrituras árabes", nos. 21 and 73.

${ }_{20}$ See Seco de Lucena, "Escrituras árabes", nos. 1 and 76; Seco de Lucena, Documentos arábigo-granadinos, nos. 63, 64 and 94.

${ }^{21}$ See Seco de Lucena, "Escrituras árabes", no. 25 and edited in Seco de Lucena, L., Privilegios Reales y viejos documentos, VII, Granada. Reino Nazari, Madrid, 1969, no. 4.

Al-Qanțara XXXII 2, julio-diciembre 2011, pp. 461-479 ISSN 0211-3589 
How long were the legal documents valid?

The third reason for the scarcity of legal documents relating to Islamic law is the idea that they were not worth keeping for generations inside a family, since they would only be valid for as long as they could be validated in court.

The evidence is clear in this matter: most of the existing documents of Granada were only issued during the second half of the 15th century ${ }^{22}$ and most of them were produced between the years 897/1491 and 898/1493, although there are also some exceptional earlier collections of Arabic legal documents not preserved in Granada. ${ }^{23}$

One of the documents shows that it was possible to update its validity. In fact, the document contains two parts of which one updates the other. ${ }^{24}$ The first one can be considered the original content, and is dated to 30 Sha'bān 835/23 April 1432, where two witnesses declare their knowledge that two persons are the owners of the surrounding areas of two houses located in the city of Baza. Written on the same piece of paper, another legal text records how 52 years later, on 30 Dhū 1-Qa'dha 889/20 December 1488, two other witnesses were able to identify the former witnesses' writing: they recognized the shape of their characters (ishkāl hurüfi-himā) and the traces of their hands. They also declared that they knew them to have been notaries in Baza (kāna min 'udūl Basta) and that they had maintained their 'adāla or honorability as witnesses until they died. ${ }^{25}$

In the same way, some of our documents are in fact copies of other earlier ones. In some cases, the copy was made much later, as in the document from the collection of the Cathedral of Guadix, ${ }^{26}$ where the original is dated to Ramadān 533/May 1139, but the certified copy was written on the 21 Sha'bān 879/31 December 1475.

${ }_{22}^{2}$ Many are dated 1460, 1476, and 1483.

${ }^{23}$ González Palencia, A., "Documentos árabes del Cenete", Al-Andalus, 5 (1940), 301-382; García de Linares, R., "Escrituras árabes pertenecientes al Archivo de Nuestra Señora del Pilar de Zaragoza", in Homenaje a D. Francisco Codera en su jubilación del profesorado, Zaragoza, 1904, 171-197; Aguirre Sádaba, F.J., "Un documento de compraventa arábigo granadino", Andalucía Islámica, 1 (1980), 63-70.

${ }^{24}$ Seco de Lucena, Documentos arábigo-granadinos, no. 2.

${ }_{25}$ Seco de Lucena, Documentos arábigo-granadinos, no. 7.

${ }^{26}$ Molina López, E., "El documento árabe de Guadix (s. XII)", in Homenaje al Prof. Jacinto Bosch Vilá, Granada, 1991, I, 271-92, 286-92. 
Otherwise, the copies are usually made only months later than the originals, so that they do not significantly prolong the lives of the documents. ${ }^{27}$

\section{Social groups and their documents}

According to Michael Chamberlain, families and households in Medieval Damascus who had rights and privileges to preserve did not need legal documents as instruments for maintaining and holding onto their power; they relied on their inclusion in cultural elites in which knowledge meant power, and this remained stable over time. ${ }^{28}$ Chamberlain refers to intellectual elites, but it seems unlikely that this assumption would be applicable to other social groups. It certainly cannot be applied to the society of Granada.

In Granada, all groups had access to documents. They visited notaries regularly and even "adopted" them as counselors in legal matters. ${ }^{29}$ They knew the legal value of documents and how important they could be for identifying and maintaining their rights and properties in cases of litigation. The royal Nasrid family and members of the great families of Granada are mentioned as parties in documents where their property was identified and transferred. ${ }^{30}$

Obviously, the Nasrid family constitutes an exception, but its members were in possession of the required written evidence of their ownership when they were forced to sell their properties to the Catholic Monarchs immediately after the Conquest of Granada, just as every seller might have done in the previous Muslim period. And Hernando de Zafra, as representative of the King, was there to accept them. ${ }^{31}$

27 Molina López, E., "Un nuevo fondo de documentos árabes granadinos. Archivo de la Catedral de Granada", Orientalia Lovaniensia Analecta, 52 (1993), 275-92, nos. 11, 12; Seco de Lucena, Documentos arábigo-granadinos, nos. 44, 49.

${ }^{28}$ Chamberlain, Knowledge and Social Practice, 14.

${ }^{29}$ For criticism by Ibn al-Khatî b of the "excessive" closeness between the people and the notaries, and the economic profit they made out of it, see Turki, A., "Lisān alDīn Ibn al-Ȟațīb (713-76/1313-74), juriste d'après son oevre inédite: Mutlā al-țarīqa fì damm al-watîqa", Arabica, 16 (1969), 155-211 (ed. in pp. 279-312).

${ }^{30}$ For the elite families mentioned in the documents, see Seco de Lucena, L., "Notas para el estudio de Granada bajo la dominación musulmana", MEAH, 1 (1952), 27-49.

${ }^{31}$ Gaspar Remiro, M., Granada en poder de los Reyes Católicos (Años 1492-1494), Granada, 1912, 72, 92.

Al-Qanțara XXXII 2, julio-diciembre 2011, pp. 461-479 ISSN 0211-3589 
In fact, the Convento de las Comendadoras de Santiago preserves a total of seventeen Arabic legal documents. Fifteen of them concern the sales of parts of a large orchard, called 'Ișām (jannat 'Ișām), divided into small plots of land. The seller is Abū l-Qāsim b. Muhammad b. Sūda, who acts as representative of the last Nasrid king Abu 'Abd Allāh. All the sales are dated to 30 Jumādā I 896/10 April 1491..32

In addition to these, the collection also contains a record of the sale made by a certain Fātima, member of the Nasrid family, of another piece of land situated in the quarter of al-Fakhkhārīn in Granada, which is also in the surroundings of 'Ișām orchard. ${ }^{33}$

The documents also reflect the transactions made by merchants and other owners of pieces of lands, houses or shops.

\section{Mudejar period (1492-1500)}

During the Nasrid period, all groups developed a way of keeping legally valid instruments to ensure their rights, which enabled them to hold onto their properties during their lifetimes. However, the reaction of the inhabitants of Granada towards their documents would be different depending on the stability or instability of their situations in two historical periods: the Mudejar (1492-1500) and the Morisco (from 1500 on). The sales made by the Nasrids can perhaps be understood as a kind of preparation for the imminent fall of the kingdom into Christian hands. They may have known that, in the near future, they would have to alter their strategies for establishing proof and evidence. In fact, the Mudejar period in Granada, usually understood as the eight years between the fall of the city and the conversiones generales, could in this light be said to have started a few years earlier, in the 1480 s.

32 Seco de Lucena identifies these transactions with the narrative of Hernando de Baeza, who mentions a non-legal acquisition made by the Nasrids of certain posesiones de la corona Real. He explains that, in order to avoid losing their properties completely, the king made a fictitious sale, or at least a non-legal one, as he soon obliged the buyers to give the properties back for compensation that was less than the price they had paid before. See Baeza, Hernando de, Las cosas que pasaron entre los reyes de Granada desde el tiempo de el rey don Juan de Castilla, in Müller, M.J., Die Letzten Zeiten von Granada, Munich, 1863, 70-71.

${ }^{33}$ The difficulty of identifying this Fatima, makes me think that the date might be erroneous.

Al-Qanțara XXXII 2, julio-diciembre 2011, pp. 461-479 ISSN 0211-3589 
Even if Granada was in the hands of the Christians from 897/1492 on, the Arabic legal documents were still issued according to Islamic law. There are no visible differences between the documents drafted in, say, 1455 and others written in 1493.

The text of the Capitulaciones was clearly applied at first and must have been a source of reassurance, since the validity of the documents was guaranteed. ${ }^{34}$

Another document preserved in the Convento de Santiago contains records of another two sales, where two persons sell to Andrés Calderón (Andrash al-Qald Qandarūn) two orchards and a house, on 19 Jumādā II 897/19 March 1492 and 23 Jumādā II 897/23 March 1492. ${ }^{35}$ Andrés Calderón was described as none other than the $q \bar{a}$ 'id al-nașrānī al-qāộ̀ al-hakìm 'an salāțīn qashtalah al- 'ālim bi- 'ulūmihim wa-sāhib siyāsati-him (the Christian qa' 'id, judge of the Kings of Castile, the greatest scholar of all their sciences and head of their politics). In fact, together with Hernando de Zafra, Andrés Calderón was in charge of the agreements and negotiations made between the Nasrid royal family and the Catholic Monarchs. ${ }^{36}$ It is curious that a man so close to the new monarchs seems to have had no qualms in relying on the Muslim notaries in order to legally guarantee his newly acquired propriety in Granada.

The archive of the Colegio de Niñas Nobles,${ }^{37}$ contains three documents, two of them drafted in the Mudejar period. The first one, from 1 Șafar 898/21 November 1492, is a written declaration of witnesses, certifying that two persons were still the owners of the upper floor of a shop (mașriyya) in Granada.

As an example of documents produced during the Mudejar period, the Archivo Municipal de Granada is especially relevant, since it holds ten Arabic legal documents, only two of them issued before 1492. Perhaps the most illustrative of them is a certificate signed by thirteen witnesses who testified and agreed on the good personal qualities and

${ }^{34}$ In the early Mudejar period, the validity of "deudas y títulos de propiedad nazaríes", was never contested. On this, see Galán Sánchez, A., Los mudéjares del Reino de Granada, Granada, 1991, 88 and López de Coca Castañer, "Las capitulaciones y la Granada mudéjar".

${ }^{35}$ Seco de Lucena, Documentos arábigo-granadinos, no. 81.

${ }^{36}$ Gaspar Remiro, Granada en poder de los Reyes Católicos, 37.

37 Seco de Lucena, L., "Documentos árabes granadinos. I. Documentos del Colegio de Niñas Nobles", Al-Andalus, 8 (1943), 415-29.

Al-Qanțara XXXII 2, julio-diciembre 2011, pp. 461-479 ISSN 0211-3589 
reputation of Abū 1-Ḥasan b. Muḥammad b. 'Abd al-Raḥmān, meaning that he was suitable to be alguazil or governor (wazìr) in Purchil (qaryat Burjīl). The document dates from the middle of Jumādā I 900/11 February 1495. According to Molina and Jiménez Mata, the lack of expertise of the Castilians in the administration of the Muslim population made it necessary not only for a Mudejar spokesman to be present, but also an alguazil, a judge ( $q \bar{a} d \bar{l} \bar{l})$, and a legal expert (faqīh), in order to carry out judicial and religious functions.

The new Christian administration needed the Arabic legal documents for its rule, and therefore the document was issued following the usual Islamic formula for the appointment of a trustworthy person for fulfilling a function. ${ }^{38}$ At the end of the document, immediately following the text, the names of the thirteen witnesses are aligned with the word "testified" over each of them. They might have been the members of the "council" composed of good and old men selected from the most influential authorities in the area. As in other documents of this kind, the text finishes with the necessary validation by the judge, here the representative of the shari' $a$ in Granada ( $a l$ nā'ib fí l-hukm al-shar 'ci bi-Gharnāta $)^{39}$

The production of Arabic legal documents according to Islamic law is very well represented in the different collections of Granada: all of them have Mudejar documents, and this should always be understood as an essential reason for their eventual survival. ${ }^{40}$

\section{Documents and owners}

An initial study of the names of the parties mentioned in the documents shows a limited number of owners as well as a limited number of properties. All of the documents seem to be related and linked by social and economic factors to each other. ${ }^{41}$

${ }^{38}$ See, for example, Seco de Lucena, Documentos arábigo-granadinos, no. 1.

39 Molina López and Jiménez Mata, "From Muslim to Christian Hands", 25-26.

${ }^{40}$ In the collection located in Fondo Antiguo, in the Biblioteca del Hospital Real, 21 documents out of 156 were issued between 1492 and 1500; the Archivo Municipal de Granada has eight out of ten; the Archivo de la Catedral has 42 out of 71.

${ }_{41}$ Zomeño, A., "Documentos árabes y biografías mudéjares: Umm al-Fath al-Salyān̄̄ y Muḥammad Bahțān (1448-1496)", in A. Echevarría (ed.), Biografías mudéjares o la experiencia de ser minoría: Biografías islámicas en la España cristiana, Madrid, 2008, 291-325 and Zomeño, A., “'When Death Will Fall Upon Him': Charitable Legacies in 15th Century Granada", in M. Frenkel and Y. Lev (eds.), Charity and Giving in Monotheistic Religions, Berlin-New York, 2009, 217-233. 
Although these documents still reflect the sale of some properties by Muslims to other Muslims, we typically find the selling of immovable properties to Christians. Again in the Archive of Niñas Nobles, a document contains a sale contract by which the Christian Gonzalo Delgadillo (al-nașrānī Ghunsaluh dhì l-ghadhiyyuh) bought a house from Muhammad b. 'Abd al-Ḥaqq b. al-Sirrāj on 29 Dhū 1-Hijja 898/10 October 1493.

But the most illustrative example in this regard is the collection of the Cathedral of Granada, ${ }^{42}$ because apart from the fact that most of the documents refer to the same area in the surroundings of Granada, in the qarya al-Lițākh, $90 \%$ of the property sold in this area was bought by only one person, Alfonso de Toledo, the son of Pedro González de Talavera. ${ }^{43}$ According to M.D. Rodríguez Gómez, Luis Cavero, the founder of the archive, managed in no more than five years to acquire all the properties mentioned in the documents of the collection, which were already in the hands of a very limited number of owners. ${ }^{44}$

In the Nasrid period, Granadan families did not develop an archival mentality, but every family would cherish a small number of documents for identifying and maintaining their properties.

During the Mudejar period, the Muslims started to sell their properties to the new Christian inhabitants of Granada, who kept the records of those sales produced after 1492. This explains the survival of sale contracts between Muslims and Christians, but not that of previous documents relating to the transmission of property among Muslims and the acquisition of rights during the Muslim period, which, in fact, make up the largest part of the collections. Two explanations are possible here. First, the survival of documents should

${ }^{42}$ This collection was first inventoried, together with all the archive of the Cathedral, by Casares Hervás, M., Archivo Catedral. Inventario General, Granada, 1965. See also Calero Palacios, M.C., Capel García, M.M. and Lorca González, C.I., "El mayorazgo de don Luis Cabero: un importante legado documental en el Archivo de la Catedral de Granada (1497-1520)", Cuadernos de Estudios Medievales y Ciencias y Técnicas Historiográficas, 20 (1995), 143-201. For the collection of Arabic documents in particular, see Molina López, "Un nuevo fondo" and a partial edition in Molina López, E. and Jiménez Mata, M.C., "La propiedad de la tierra en la Vega de Granada a finales del siglo XV. El caso de Alitaje", Anaquel de Estudios Árabes, 12 (2001), 449-79.

${ }^{43}$ Molina López, "Un nuevo fondo de documentos árabes granadinos", 284.

${ }^{44}$ Rodríguez Gómez, M.D., "La Porte d'al-Murdi de Grenade à travers deux documents notariaux arabes (1493)", Arabica, 56 (2009), 235-268.

Al-Qanțara XXXII 2, julio-diciembre 2011, pp. 461-479 ISSN 0211-3589 
always be understood and studied inside a collection and all of them include some documents relating to the transmission of property from Muslim to Christian hands. The other explanation is conversion: how did the new converts behave with their documents? Undoubtedly, further studies of the names and internal coherence of the collections will help to improve our knowledge of their archival mind.

\section{The Christian Tabula Rasa}

Finally, one of the reasons given by some scholars for the scarcity of Arabic legal documents, especially as relating to the history of al-Andalus, was intentional destruction. The new Christian owners might have wanted to destroy the traces of the Muslim past of the Iberian Peninsula. ${ }^{45}$ The legal documents were a part of the Muslim legacy so their destruction should not be denied. This is therefore clearly one of the reasons for the scarcity of documents. However, in Granada the destruction process meant a gradual devaluation of the function previously fulfilled by the Arabic legal documents. As far as I know, the last Arabic legal document issued in al-Andalus was dated to 6 Jumādā I 905/9 December 1499. ${ }^{46}$

During the Mudejar period, the individuals showed and openly brandished the Arabic documents issued according to Islamic law. In the Morisco period these documents were examined and translated, but more importantly, they were no longer kept in private collections, but given to institutions and newly founded institutional archives.

The archive of the Convento de Santiago received the Arabic documents at about the time of its foundation in 1501. The history of this institution was legally linked to these seventeen Arabic texts because the convent is located in precisely the same place where the 'Ișām orchard and the al-Fakhkhārīn quarter were to be found during the Nasrid period. The documents may therefore have gone in the same

${ }^{45}$ Manzano, Conquistadores, emires y califas, 393. P. Guichard was surprised by the scarcity of Arabic documents dated prior to the Christian conquest of Valencia, given the intense and inevitable contacts between Christians and Muslims during the period. These documents, according to Guichard, "did not have many opportunities to survive more than their validity period" and "we should add the voluntary destruction in the Morisco period", see Guichard, Al-Andalus frente a la conquista, 28.

46 Molina López, "Un nuevo fondo de documentos árabes", 287.

Al-Qanțara XXXII 2, julio-diciembre 2011, pp. 461-479 ISSN 0211-3589 
direction as the properties given to the institution, i.e. from the hands of Abū 'Abd Allāh to the convent via Hernando de Zafra or Andrés Calderón, the representatives of the Catholic Monarchs in Granada. To our knowledge, the texts were never translated into Romance.

The case of the archive of the Cathedral of Granada might have been similar. In 1504, Luis Cavero decided not to keep his Arabic documents at home and took them to the newly founded archive of the Cathedral, inside a large wooden box. ${ }^{47} \mathrm{He}$ did so at the same time that he decided to legate all of his estate to one of his nephews, thereby forever linking the record of his legacy to the Arabic documents in the archive.

However, in many cases, legal documents written in Arabic and evoking a Muslim past were not destroyed, because of litigation and pleitos which arose involving the new Christian administration. For example, in 1535, there was litigation between the council of Baza and the Vélez family concerning the limits, ownership and usage rights of certain lands. A summary of the litigation is preserved in the Municipal Archive of Baza. ${ }^{48}$ The city of Baza's desire to strengthen its claim led it to present as evidence several documents written in Arabic.

Although the originals did not survive, we can deduce what they were like from the summary, where they are described as very old, going back nearly 120 years, and the "qadis, faqihs and kings who made them and signed them were already dead, so that it will be impossible to find someone who would remember them or would know their signatures". ${ }^{49}$ However, this was not an impediment for using these materials: an examination of the validity of the documents "according to the uses of the Muslims" was requested,${ }^{50}$ and they were given to Miguel de León, ${ }^{51}$ who was a judge and legal scholar under Muslim rule. De León considered them authentic documents because of the shape and location of their dates, signatures, authorisations and validations made according to the "xara

47 Rodríguez Gómez, "La Porte d'al-Murdi de Grenade", 240-241.

${ }^{48}$ I owe the transcription of this case to Clara Almagro and Francisco Javier Crespo Muñoz.

${ }^{49}$ Leg. 90 , fol. $435 \mathrm{v}$.

${ }^{50}$ Leg. 90, fol. 436r.

${ }^{51}$ Miguel de León was "veynte y quarto" in the city of Granada, and included in 1533 among the new converts: see document no. 12 in Los Moriscos. Españoles trasterrados, Madrid, 2009, 80-81. 
e çuna de moros". ${ }^{52}$ They were sent to Granada for their translation into Romance by Bernardino Xarafi, an official translator in the city. ${ }^{53}$ Finally, since the Arabic documents were crucial in the case, translations of them were included in the summary of the lawsuit together with the transcription in Arabic. ${ }^{54}$ The originals in Arabic were given back to the council of Baza.

The five documents transcribed are dated between $13 \mathrm{Rabi}^{\circ} \mathrm{I}$ 802/13 November 1399 and 7 Jumādā I 805/13 December 1402. They record the sale of certain plots of land by the Nasrid kings to the city of Baza, and the authorizations and mandates carried out in order to validate this transaction.

It is obvious, then, that the city council and municipality of Baza kept the documents for at least 87 years under Muslim rule and another 46 in the Christian period, when they proved to be useful in litigation.

The three Arabic legal documents preserved in the Colegio de Niñas Nobles belonged to a woman, Juana de Berrio, a member of a family that fought in the conquest of Granada. She may have acquired these documents as an inheritance, together with other properties. ${ }^{55} \mathrm{In}$ 1548 , she still possessed the documents but did not know their meaning since they were in Arabic. She therefore decided to have them translated into Romance and for this purpose she commissioned a certain Bartolomé de Herrera. Bartolomé gave the documents to the translator Juan Rodríguez who, at the head of the translated text, explains how Juana de Berrio had these Arabic documents as "títulos de propiedad de unas casas que en ella haze minción" (ownership titles of some houses mentioned therein) and that it was now convenient for her rights to have them "in Castilian language and script" ${ }^{56}$

${ }_{52}$ Leg. 90 , fol. $437 \mathrm{v}$.

53 Bernardino Xarafi made the translation with two other witnesses, Miçer Ambrosio Xarafi and Francisco Jimenez Zayd. On this translator, see Feria García, M.C. and Arias Torres, J.P., "Un nuevo enfoque en la investigación de documentación árabe granadina romanceada (ilustrado con dos traducciones inéditas de Bernardino Xarafi, escribano y romanceador del Reino de Granada)", Al-Qantara, 26 (2005), 191-248.

${ }^{54}$ The full edition and translation of the Arabic documents was made by E. Molina López and M.C. Jiménez Mata. To both I am indebted. In fact, we are currently preparing a book which will include a study of the whole litigation process.

${ }^{55}$ Seco de Lucena, "Documentos árabes granadinos. I. Documentos del Colegio de Niñas Nobles", 415-29.

${ }^{56}$ Seco de Lucena, "Documentos árabes granadinos. I. Documentos del Colegio de Niñas Nobles", 29. 
In other words, Arabic documents were still considered worth keeping and translating as late as 1548 , as they might have internal contents useful for the Christian population. Although she required a translation to be made, Juana de Berrio held onto the original Arabic documents, but these were eventually given to the institution where they are now held.

Arabic documents did not have a religious or doctrinal content, but a legal one that was considered useful for the new owners of Granada. Their contents were at first appreciated and even deemed indispensable, as we can see from the way they were used in the litigation of Baza, but also from the explanations given by Juana de Berrio to the translator Juan Rodríguez. This was also the reason why Luis Cavero and the Convent of Santiago kept the documents, since they were aware of their value for identifying the property and its transmission. The fact that they were written in Arabic was an additional bonus that reminded their owners of the way the properties were acquired immediately after the conquest: they became symbols for the conquerors.

The translation of Arabic documents was always preceded by a careful examination of their legal value and a corroboration of their validity in the Nasrid and Mudejar period. Fortunately, this did not impede the keeping of the originals in Arabic, but the enormous amount of Islamic legal documents in Romance translation rather than in their original language should not be neglected if we are to arrive at a better understanding of archival mentalities. ${ }^{57}$

However, the situation in Granada was changing day by day. During the first part of the 16th century, Arabic was still a language of Granada. In 1500, there was a Royal decree for the new converts to follow the Psalms and prayers in Arabic, ${ }^{58}$ and Hernando de Talavera would even finish mass in the Albaicín quarter by saying ybara fiqun instead of the dominus vobiscum. ${ }^{59}$ However, by 1566, the Arabic language was much more widely considered the main tool for pres-

${ }^{57}$ For the Romanceado documents, see Osorio Pérez, M.J., and Santiago Simón, E. de, Documentos arábigo-granadinos romanceados, Granada, 1986; Álvarez de Morales, C., "Romanced Documents, Bilingual Documents and Books of Habices", in Sijpesteijn, Sundelin, Torallas and Zomeño (eds.), From al-Andalus to Khurasan, 3-21.

${ }_{58}^{58}$ Los Moriscos. Españoles trasterrados, 62.

${ }^{59}$ See García-Arenal, M. and Rodríguez Mediano, F., Un Oriente español. Los moriscos y el Sacromonte en tiempos de Contrarreforma, Madrid, 2010, 48.

Al-Qanțara XXXII 2, julio-diciembre 2011, pp. 461-479 ISSN 0211-3589 
ervation of the memory of Islam: "through this language, they [i.e. the new Christians] preserved and maintained the memory of their former and damaged sect and life". As a result, any Arabic writing was declared null and without legal effect from this moment on. ${ }^{60}$

This was equivalent to depriving the documents of their original value and meant the end of the transfer system from Muslim to Christian hands. The order prompted the revolt of the Alpujarras, as the rebels were losing their properties and rights in a world where their documents were no longer seen as acceptable.

\section{Conclusions}

In general terms, the survival of documents for long periods depends on the archival mentalities displayed by the members of a society, and this in turn is developed through an appreciation of their value which justified their safeguarding from destruction.

The collections of Arabic legal documents of Granada endured over the centuries because they were given to the archives of a new society in which the Islamic past was still considered useful for practical and economic reasons, even if this value was soon to change.

However, this new Christian society was only able to keep what was found available, and they certainly did not encounter archives kept systematically by Muslim institutions. What they found instead were groups of documents, small private collections.

Recibido: $22 / 04 / 2011$

Aceptado: 30/05/2011

${ }^{60}$ García-Arenal, M., Los Moriscos, Madrid, 1975, 55; Los Moriscos. Españoles trasterrados, 89.

Al-Qanțara XXXII 2, julio-diciembre 2011, pp. 461-479 ISSN 0211-3589 